\title{
Regulatory Immunotherapy in Bone Marrow Transplantation
}

\author{
Vanessa Morales-Tirado, Wioleta Luszczek, Marié van der Merwe, and Asha Pillai \\ Department of Bone Marrow Transplantation and Cellular Therapy, St. Jude Children's Research Hospital, \\ 262 Danny Thomas Place, Memphis, TN 38105, USA
}

Received 10 August 2011; Accepted 12 October 2011

Academic Editors: N. Miyahara, Y. Renaudineau, and J. Sidney

Every year individuals receive hematopoietic stem cell transplantation (HSCT) to eradicate malignant and nonmalignant disease. The immunobiology of allotransplantation is an area of ongoing discovery, from the recipient's conditioning treatment prior to the transplant to the donor cell populations responsible for engraftment, graft-versus-host disease, and graft-versus-tumor effect. In this review, we focus on donor-type immunoregulatory $T$ cells, namely, natural killer $T$ cells (NKT) and regulatory T cells (Treg), and their current and potential roles in tolerance induction after allogeneic HSCT.

KEYWORDS: Allogeneic transplantation, regulatory T cells, NKT, GVHD, GVT, immunoregulation, transplant tolerance 


\section{INTRODUCTION}

Elegant studies by Barnes et al. [1,2] demonstrated that the infusion of allogeneic bone marrow cells may destroy recipient tumor cells, indicating the possibility of cytotherapeutic antitumor potential in the transplanted allogeneic cellular graft (graft-versus-tumor activity, GVT). Some animals clearing leukemic cells died of a secondary "wasting disease" consisting of diarrhea, weight loss, skin inflammation, and liver disease. This was the first clinical description of lethal graft-versus-host disease (GVHD) in a murine model [3]. Parallel studies of human bone marrow transplantation for malignancies by Mathe and colleagues focused on attempts to achieve GVT without fatal GVHD, but these were complicated by lack of sustainable engraftment of donor hematopoietic cells. By combining total body irradiation (TBI) with infusion of allogeneic bone marrow, Thomas's group in 1959 demonstrated the first leukemia cure by HSCT [4]. Although this patient died from complications of GVHD, no residual leukemia cells were found. It became evident that although allotransplantation could be curative for hematologic malignancies, GVHD would remain the major hurdle for success. Finally, in 1965, Mathe's group reported a case of successful longterm engraftment without GVHD after allogeneic bone marrow transplantation [5].

Nearly 50 years later, GVHD and graft rejection continue to limit the curative application of allogeneic bone marrow transplantation (BMT), both for malignant and nonmalignant hematologic conditions. GVHD is mediated by an immune attack by the donor effector T cell population within the graft against key target tissues of the recipient or graft-versus-host $(\mathrm{GVH})$ reactivity, whereas graft rejection is mediated dominantly by effector $\mathrm{T}$ and NK cells responses of the recipient against the donor graft, termed host-versus-graft (HVG) reactivity [6, 7]. Both GVH and HVG reactivities are augmented immunologically by tissue damage and release of proinflammatory cytokines, which characterize conventional TBIcontaining pretransplant conditioning regimens. In 1966, Billingham identified the criteria associated with the development of GVHD as (1) MHC disparity between donor and recipient, (2) immunocompetent cells in the graft, and (3) the ability of the host to accept the graft (relative HVG hyporeactivity) [8]. The target organs of GVHD include the skin, liver, and the intestinal tract. Studies using antithymocyte globulin (ATG), and more recently the use of monoclonal antibodies to deplete $\mathrm{T}$ lymphocytes, revealed that contaminating mature $\mathrm{T}$ cells from the donor recognize the recipient's histocompatibility antigens. Paradoxically, $\mathrm{T}$ cells are also required for cytotoxic T lymphocyte (CTL) effector function, which are central to GVT activity. Thus, the "Holy Grail" in allotransplantation is to maintain GVT (and antimicrobial/antiviral) activity while facilitating the engraftment of the donor hematopoietic stem cells, and avoiding GVHD mediated by mature T cells within the donor graft.

The immune mechanisms regulating GVHD need to be clearly understood for development of rational treatment, and ideally, better preventive strategies. Understanding immunoregulatory networks in both murine models and man is thus indispensable for novel therapeutics. This review will focus on our current understanding of the immunobiology of regulatory cells from both the innate and adaptive arms of the immune system as vehicles for treatment and prevention of GVHD (Figure 1), using both preclinical and clinical studies in allogeneic BMT.

\section{INNATE REGULATORY CELLS: NATURAL KILLER T CELLS}

An effective immune response requires the integration of the innate and adaptive arms of immunity, initiated by triggering of antigen-presenting cells (APCs). In allotransplantation, APCs of both recipient and donor are dominant sensors of the disparity between major histocompatibility complex (MHC) and peptide complexes, and they play roles in both antigen presentation and costimulation. Immunoregulatory cells of the innate immune system can modulate the function of and be modulated by both donor and recipient APCs.

Natural Killer T (NKT) cells (reviewed in $[6,9,10]$ ) are considered innate immune regulatory cells due to the acquisition of effector function during development, rather than postantigen exposure. During an early immune response, recruited NKT cells produce high concentrations of cytokines that 


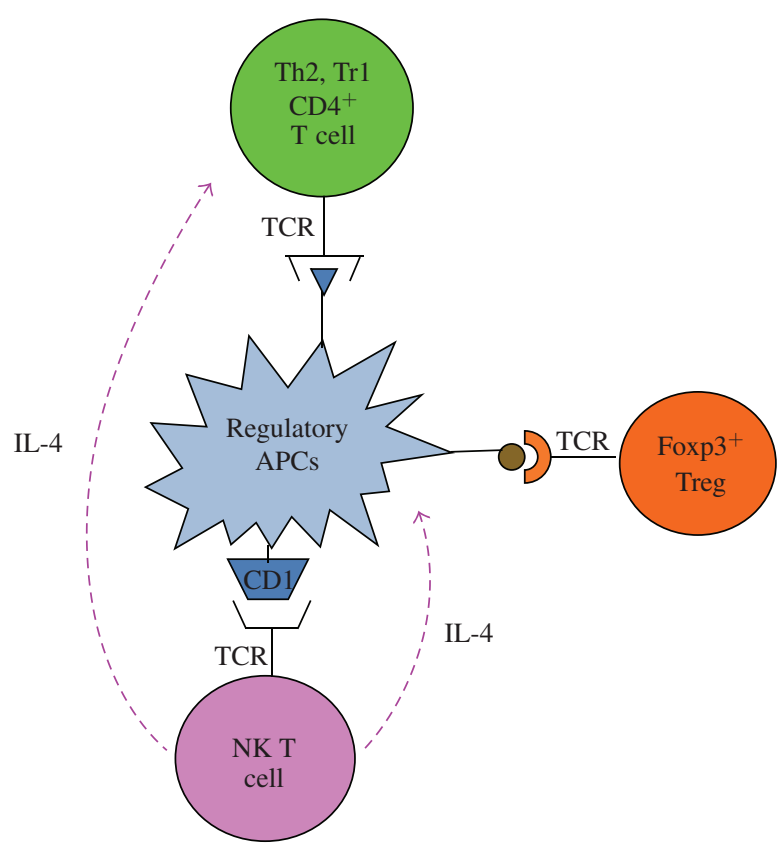

FIGURE 1: Model for host-donor immunoregulation after nonmyeloablative BMT. Figure illustrating key regulatory populations in host and donor and the potential for interactive regulation across major and minor histocompatibility complex barriers after allogeneic BMT. NKT cells, through potent of cytokines secretion including IL-4, can directly regulate the effector T cells responsible for GVHD; NKT cells can also induce the activation and proliferation of Treg from the donor graft, which in turn regulate effector Tcell-mediated GVHD. NKT: natural killer T; Th2: T-helper type 2; $\mathrm{Tr} 1$ : Foxp3 ${ }^{\text {neg }} \mathrm{CD}{ }^{+} \mathrm{IL}-10^{+}$regulatory $\mathrm{T}$ cell; IL-4: interleukin-4.

alter the microenvironment for activation and recruitment of other immune cells including $\mathrm{T}$ effector cells $\left(\mathrm{CD} 3{ }^{+} \mathrm{CD} 4{ }^{+} \mathrm{CD} 25^{\text {neg }}\right.$ and $\left.\mathrm{CD} 3{ }^{+} \mathrm{CD} 8^{+} \mathrm{CD} 25^{\text {neg }}\right), \mathrm{CD}^{+}{ }^{+} \mathrm{CD} 25^{+} \mathrm{Foxp}^{+}$regulatory cells (Treg), and both professional APCs such as dendritic cells (DCs) and nonprofessional APCs. NKT cells can be divided into two main subsets. Both subsets are activated through glycolipid antigen presentation by the MHC Class I-like molecule CD1d. The endogenous glycolipid ligand(s) presented by CD1d remains elusive, though a subject of aggressive investigation. The exogenous glycolipid $\alpha$-galactosylceramide ( $\alpha$-GalCer) [11], derived from the marine sponge, is the prototypical reagent used for NKT cell activation. Contrary to conventional effector T cells, the response of NKT cells to cognate antigens is not restricted by MHC-Class I or II molecules. Type I NKT cells, commonly known as invariant NKT (iNKT), have an invariant TCR-J $\alpha$ chain. Type II NKT cells are less well understood, can have a noninvariant TCR-J $\alpha$ chain, and may have diverse TCR- $\mathrm{V} \alpha$ and $-\mathrm{V} \beta$ rearrangements.

\section{IMMUNOREGULATION BY NKT CELLS}

Pivotal studies from multiple laboratories have characterized a novel subpopulation of $\mathrm{CD}^{-} \mathrm{CD} 8^{-}$(DN) NKT cells which not only do not initiate GVHD, but also inhibit the graft-versus-host immune response following MHC-mismatched BMT. Using C57BL/6 $\left(\mathrm{H}-2^{\mathrm{b}}\right) \rightarrow \mathrm{BALB} / \mathrm{c}\left(\mathrm{H}-2^{\mathrm{d}}\right)$ and BALB/c $\rightarrow$ C57BL/6 allogeneic transplant models, Zeng and colleagues compared peripheral blood (PB)- and bone marrow (BM)-derived sorted $\mathrm{CD}^{+}$and $\mathrm{CD}^{+} \mathrm{T}$ cells of donor mice to $\mathrm{T}$ cell depleted bone marrow injected into lethally irradiated host mice in their ability to induce GVHD [12]. PB-derived control cells were potent inducers of GVHD. Using NK1.1 selection, known now to select both noninvariant and a subset of iNKT cells, BM-derived sorted cells were tested for their ability to induce GVHD. NK1.1 ${ }^{-}$effector CD4 ${ }^{+}$ 
TABLE 1: Murine models of immunoregulatory cells in hematopoietic cell transplantation.

\begin{tabular}{|c|c|c|c|}
\hline Immunoregulatory cell & Reference & Model & Contributions \\
\hline \multirow{5}{*}{$\begin{array}{l}\text { Natural killer T (NKT) } \\
\text { Cells }\end{array}$} & Lan et al. [17] & $\begin{array}{l}\text { MHC-mismatched } \\
\text { C57BL/6 } \rightarrow \text { BALB/c }\end{array}$ & $\begin{array}{l}\text { (i) TLI and ATS regimen } \\
\text { increases recipient } \\
\text { NK1.1 } 1^{+} \mathrm{TCR} \alpha \beta^{+} \text {cells. } \\
\text { (ii) Recipient } \mathrm{NKT} \text { cells } \\
\text { mediate GVHD protection. }\end{array}$ \\
\hline & Hashimoto et al. [18] & $\begin{array}{l}\text { MHC-mismatched } \\
\text { BALB/c } \rightarrow \text { C57BL/6 }\end{array}$ & $\begin{array}{l}\text { (i) } \alpha \text {-Gal-Cer treatment of } \\
\text { recipients. } \\
\text { (ii) Recipient } \mathrm{NKT} \text { cells } \\
\text { mediate GVHD protection } \\
\text { via IL-4. }\end{array}$ \\
\hline & Pillai et al. [19] & $\begin{array}{l}\text { MHC-mismatched } \\
\text { C57BL/6 } \rightarrow \text { BALB/c }\end{array}$ & $\begin{array}{l}\text { (i) TLI/ATS regimen. } \\
\text { (ii) Recipient NKT cells } \\
\text { regulate GVHD without } \\
\text { inhibiting GVT. }\end{array}$ \\
\hline & $\begin{array}{l}\text { Leveson-Gower et al. } \\
\text { [20] }\end{array}$ & $\begin{array}{l}\text { MHC-mismatched } \\
\text { C57BL/6 } \rightarrow \text { BALB/c }\end{array}$ & $\begin{array}{l}\text { (i) Donor NKT cells regulate } \\
\text { GVHD without inhibiting } \\
\text { GVT, via IL- } 4 \text {. }\end{array}$ \\
\hline & Taylor et al. [54] & Ex vivo allo-MLR: & $\begin{array}{l}\text { (i) Tolerance is dependent on } \\
\text { presence of } \mathrm{CD} 4^{+} \mathrm{CD} 25^{+} \mathrm{T} \\
\text { cell fraction. }\end{array}$ \\
\hline \multirow[t]{2}{*}{$\begin{array}{l}\text { Regulatory T cells } \\
\text { (Treg) }\end{array}$} & Hoffmann et al. [55] & $\begin{array}{l}\text { MHC-mismatched } \\
\text { C57BL/6 } \rightarrow \text { BALB/c }\end{array}$ & $\begin{array}{l}\text { (i) Donor Treg protects } \\
\text { against lethal GVHD induced } \\
\text { by donor cells through IL-10 } \\
\text { production. }\end{array}$ \\
\hline & Edinger et at. [56] & $\begin{array}{l}\text { MHC-mismatched } \\
\text { C57BL/6 } \rightarrow \text { BALB/c }\end{array}$ & $\begin{array}{l}\text { (i) Donor Treg GVHD } \\
\text { protection does not alter } \\
\text { GVT. }\end{array}$ \\
\hline NKT-Treg interaction & Pillai et al. [21] & $\begin{array}{l}\text { MHC-mismatched } \\
\text { C57BL/6 } \rightarrow \text { BALB/c }\end{array}$ & $\begin{array}{l}\text { (i) TLI/ATS regimen. } \\
\text { (ii) Recipient iNKT induces } \\
\text { donor Treg proliferation to } \\
\text { suppress GVHD. }\end{array}$ \\
\hline
\end{tabular}

MHC: mouse major histocompatibility complex; TLI: total lymphoid irradiation; ATS: rabbit antimouse thymocyte serum; $\alpha$-Galcer: $\alpha$ galactosylceramide (NKT-specific glycolipid ligand); IL-4: interleukin 4; IL-10: interleukin 10.

and $\mathrm{CD} 8^{+}$cells, which are high IFN- $\gamma$ producers, induced potent GVHD. This GVHD was ameliorated by the infusion of NK1.1 $1^{+}$T cells (which produced both IFN- $\gamma$ and IL-4), suggesting that NK1.1 ${ }^{+}$cells were able to regulate GVHD induced by the NK1.1- effector T cells. To test the possible contribution of cytokine secretion from the NK1.1 $1^{+} \mathrm{T}$ cell subset in regulation of GVHD, the experiment was repeated using NK1.1 ${ }^{+}$cells from IL-4-deficient donor mice. In sum, the outcome of these experiments showed for the first time that GVHD is induced by effector NK1.1 ${ }^{-}$T cells and regulated NK1.1 ${ }^{+}$NKT cells, and that amelioration of GVHD by NK1.1 ${ }^{+}$NKT cells is IL-4-dependent, at least in the setting of a major alloresponse such as MHC-mismatched BMT (Table 1). Though this data was focused on the regulatory capacity of donor NKT cells on donor effector T cell-mediated GVHD, later studies have demonstrated roles for NKT cells in alloregulation across donor-recipient MHC barriers in nonmyeloablative BMT (see below). 


\subsection{Murine NKT Cells}

Murine NKT cells constitute $0.2-0.5 \%$ of total lymphocytes. They are most frequent in liver tissue and least abundant in lymph nodes [9]. Like conventional T cells, NKT cells undergo maturation from prethymic $\mathrm{CD}^{+}$bone marrow precursors under the influence of thymic antigen exposure. Thymic cortical positive selection of NKT cells is strictly dependent on CD1d expressed on thymic epithelial cells (TEC). This has been demonstrated by absence of both iNKT and noninvariant NKT cells in CD1d knock-out (KO) mice and in CD1d KO mice given myeloablative bone marrow transplants from wild-type syngeneic donors, in which hematopoietically derived populations but not somatic epithelial tissues express CD1d. Murine NKT cells express the invariant $\mathrm{V} \alpha 14$ TCR- $\alpha$ chain and the $\mathrm{J} \alpha 18$-joining segment. J $\alpha 18 \mathrm{KO}$ mice are deficient in iNKT cells, demonstrating the conserved nature of the V $\alpha 14 \mathrm{~J} \alpha 18$ TCR [13] rearrangement in invariant NKT cells.

Phenotypically, murine NKT cells can be divided into subpopulations based on the presence or absence of the CD4 coreceptor molecule. NKT cells can have a $\mathrm{CD} 4^{+}$single positive (SP) or a CD4 ${ }^{-} \mathrm{CD} 8^{-}$ double negative (DN) phenotype. More than $70 \%$ of the total iNKT fraction in mice is subsumed by the SP subset. The functional characterization of SP versus DN iNKT has been complicated by differences in the model systems used and organ sites from which iNKT cells were isolated, which could alter the reported phenotype. These represent areas ripe for further study, in particular with respect to immunomodulatory roles of these cells. The function of a $\mathrm{CD}^{+}$subpopulation of iNKT cells in mice remains unclear. CD4 ${ }^{+}$ NKT cells produce both Th1- and Th2-type cytokines (IFN- $\gamma$ and IL-4, resp.), whereas CD8 ${ }^{+}$NKT cells show a Th1-type cytokine bias. Other cytokines produced by NKT cells include TNF- $\alpha$, IL-2, IL-10, IL13, IL-17, IL-21, IL-22, and GM-CSF. The relative functions of the noninvariant NKT versus iNKT cells in murine systems is similarly in need of specific comparative study for a number of immunoregulatory functions ascribed to NKT cells as a whole. The combination of the surface markers TCR $\alpha \beta$, CD4, CD8, and NK cell activation markers such as NK1.1 (DX5 in the BALB/c strain) and reactivity with $\alpha$ GalCer-loaded CD1d tetramer reagents aid in the identification and isolation of NKT cells from tissues. Development of a sensitive and specific anti- $\mathrm{V} \alpha 14$ monoclonal antibody would greatly aid the field of murine iNKT study.

\subsection{Human NKT Cells}

Frequency of human NKT cells in the blood is highly variable and much lower than that of murine NKT cells (0.01-0.5\%). Human NKT cells share some key phenotypic similarities with their murine counterparts. Like murine NKT cells, human NKT cells acquire effector function during development and not after maturation. They can similarly be divided into two main groups: invariant and noninvariant (Types I and II). In humans, type I (iNKT) expresses the invariant V $\alpha 24$ TCR- $\alpha$ chain subset [14], the J $\alpha 18$ conserved joining segment, and the $\mathrm{V} \beta 11$ chain. Cellular activation remains glycolipid dependent in the context of the MHC Class I-like molecule CD1d, although conflicting data exists suggesting other mechanisms of activation for other types of antigens, including viral antigens. Whereas mice express only the CD1d isoform, humans demonstrate 4 isoforms of CD1 (CD1a-d). To date, only CD1d has been shown to present glycolipid antigen to human NKT cells.

Human iNKT cells include three subsets: $\mathrm{CD}^{+}, \mathrm{CD}^{+}$, and $\mathrm{CD}^{-}{ }^{-} \mathrm{CD} 8^{-}$(DN) cells, with the dominant fraction in most studies being DN iNKT cells. High-purity isolation can be achieved by 6B11 monoclonal antibody (directed against the $\mathrm{V} \alpha 24$ chain-J $\alpha 18$ segment of the CDR3 loop of TCR) [15, 16] in conjunction with anti-CD3. Less than $40 \%$ of the cells are single positive, even during ex vivo expansion of $\mathrm{CD}^{+} \mathrm{V} \alpha 24^{+}$cells (Figure 2(a)). Cytokine production has been characterized mainly using PB-derived NKT cells. In addition to IFN- $\gamma$ and IL-4, human PB NKT cells are known to secrete TNF- $\alpha$, IL-10, IL-13, and GM-CSF. Contrary to murine NKT cells, human NKT cells, both DN and CD8 ${ }^{+}$, exhibit a predominant Th1-type cytokine profile [6]. Interestingly, differences in NKT cell cytokine profile (polarization) may also be determined by age or stage of maturation. Stimulated human cord blood-derived NKT cells have been shown to maintain a predominantly Th2 phenotype in comparison to adult PB NKT cells, 

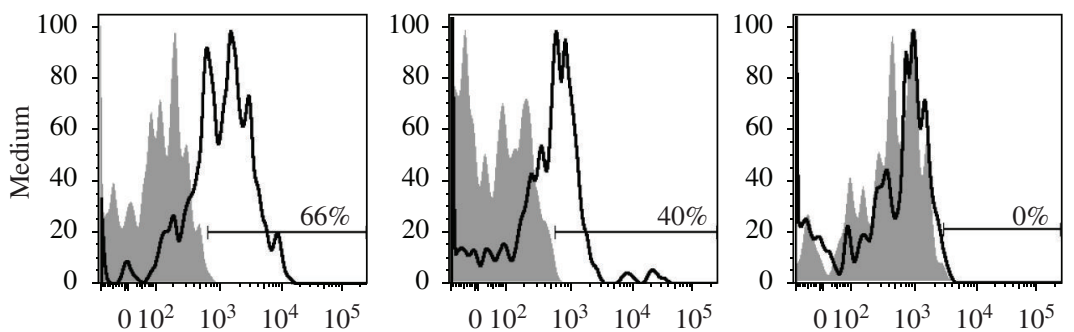

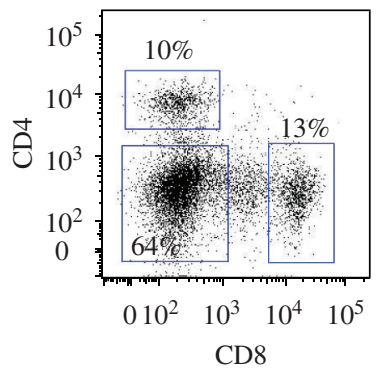

(a)

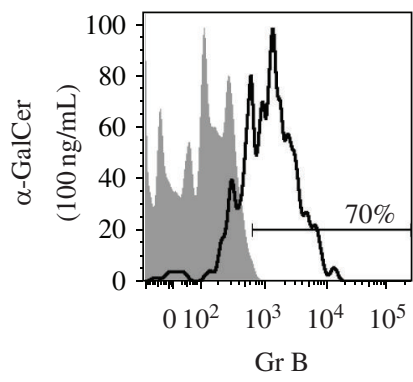

Gr B

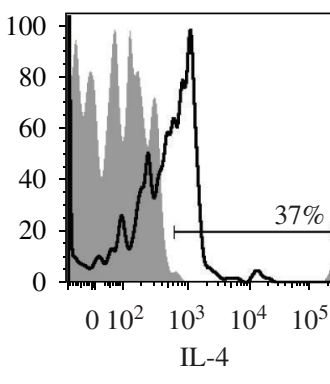

(b)

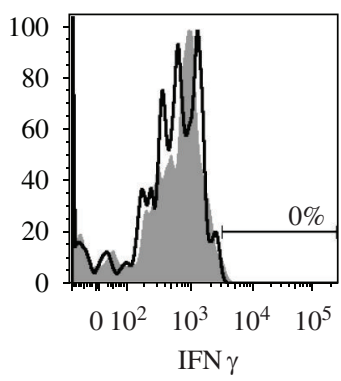

FIGURE 2: Phenotype of expanded iNKT cells. (a) PBMCs cultured for 7 days with $\alpha$-GalCer in combination with rhIL-2 and rhlL-7 followed by FACS-based cell sorting for $C D 3^{+} \mathrm{V} \alpha 24^{+}$cells. Sorted iNKT cells were cultured with allo-PBMCs feeders, anti-CD3 mAb, and rhIL-2 and rhIL-7 for 21 days. (b) Cytokine profile of expanded (day 28) iNKT cells. Cellular cultures of FACS-sorted/expanded CD $3^{+} \mathrm{CD} 4^{\text {neg }} V_{\alpha} 24^{+}$cells were stimulated for 5 hours with media alone or media $+\alpha$-GalCer. Samples were analyzed using BD LSRII equipment and FlowJo 9.3.2 software. GrB: intracellular Granzyme B.

though this can be shifted by growing NKT cells in Th1-polarizing conditions. As shown in Figure 2(b), expanded PB-derived CD4 ${ }^{+}$NKT cells exhibit a Th2 phenotype (predominant IL-4-producing cells and low/null IFN- $\gamma$ production), even when the prototype $\alpha$ Gal-Cer was used for a 5-hour restimulation at day 28 after cellular expansion (Luszczek, Morales-Tirado and Pillai, Unpublished). Our preliminary data suggests that expanded human iNKT cells maintain a Th2 cytokine profile during cellular expansion, making these cells an attractive tool for immunotherapy of Th1 inflammatory disorders including GVHD.

\section{GRAFT-VERSUS-HOST DISEASE REGULATION BY NKT CELLS}

The $\mathrm{CD}^{-} \mathrm{CD}^{-} \mathrm{DN}$ iNKT subpopulation is associated with direct antitumor activity and modulation of antitumor activity of other key immune populations such as NK cells, and transplant associated effector functions such as GVT. Type II NKT cells suppress antitumor surveillance in certain model systems, although these models were limited by the nature of the tumor model and the methods of investigation of antitumor response. In addition, NKT cells contribute to the maintenance of immune tolerance to allografts in both solid organ (cardiac) transplantation and in HSCT.

The need to reduce the undesirable toxicity of conventional myeloablative pretransplant conditioning led to the development of less intense pre-transplant preparative regimen or "conditioning" (reduced intensity conditioning, RIC) therapy that retains desirable immune effects such as GVT with reduced organ toxicity and transplant-related mortality. Nonmyeloablative conditioning relies more on immunosuppression and immune modulation and less on chemotherapy and/or radiation-mediated host immune ablation. Total lymphoid irradiation (TLI) is a nonmyeloablative regimen shown to have potent immunosuppressive effects in patients with Hodgkin's lymphoma, and other diseases. When applied as part of pretransplant conditioning of recipients for BMT, TLI protects recipients against GVHD in part by augmenting immunoregulatory cell function in both recipient and donor when compared to TBI. In 
TLI conditioning, recipient/host NKT cells persist due to their resistance to radiation-induced apoptosis (compared to conventional T lymphocytes) as well as bone marrow-sparing effects of a nonmyeloablative regimen. Murine studies have demonstrated that TLI in combination with rabbit antimouse thymocyte serum (ATS) preferentially depletes peripheral effector $\mathrm{T}$ cells, causing an increase in the relative fraction of $\mathrm{NK} 1.1^{+} \mathrm{TCR} \alpha \beta^{+}$cells in spleen and liver of recipient mice to more than $90 \%$ of all $\mathrm{T}$ cells in recipient mice [17]. This increase is associated with a Th2-cytokine shift, dominated by IL4 production, which appears to be critical to the immunoregulatory capacity of the TLI/ATS regimen when applied to allo-BMT. Protection from GVHD is lost when NKT cell-deficient recipients are used, demonstrating a central role for host NKT cells in this process [6]. Shortly thereafter, studies demonstrated in a different murine transplant model [18] that the stimulation of recipient NKT cells with the exogenously derived NKT-specific glycolipid ligand $\alpha$-galactosylceramide can allow GVHD protection, and that this protection is mediated by recipient NKT cell IL-4 acting on T cells within the donor graft.

Additional studies performed by Pillai et al. showed that iNKT cells do not inhibit the GVT potential of allogeneic BMT. Splenocytes from wild type, $\mathrm{CD}^{-/-}$, perforin ${ }^{-/-}$, or Fas ligand ${ }^{-/-}$donors $^{-1}$ were used and demonstrated that $\mathrm{CD}^{+}$peripheral $\mathrm{T}$ cells from the donor graft mediated GVT via a perforin-dependent pathway [19]. Later studies have confirmed using direct bioluminescence imaging (BLI) techniques that murine NKT cells of donor type can regulate GVHD without inhibiting GVT [20]. Given the ability of NKT cells to readily secrete cytokines that potently alter the immune microenvironment, we have continued to pursue the role of NKT cells in GVHD protection. Using the same murine model system, we have reported that recipient-type iNKT cells enriched after TLI/ATS conditioning are capable of inducing and/or maintaining the regulatory function of donor-type Foxp $3^{+}$Treg from among the peripheral $\mathrm{T}$ cells within the graft in vivo, and that this critical host-donor immunoregulatory interplay is required for the potent GVHD protection seen after TLI/ATS + BMT [21]. The induction and maintenance of donor Treg function by recipient iNKT cells was demonstrated to depend upon IL-4 secretion, which can be established after TLI/ATS by recipient Th2-polarized iNKT cells. Our most recent results (van der Merwe and Pillai, Unpublished) demonstrate that the TLI/ATS-induced Th2 polarized milieu allows the persistence of a recipient BM-derived APC population with characteristics of myeloid-derived suppressor cells (MDSCs) which suppresses $\mathrm{CD}^{+} \mathrm{T}$ cells, and may enhance the Foxp3 ${ }^{+}$Treg fraction of the donor graft.

The findings in these murine preclinical models have largely been translated to human clinical trials for acute myelogenous leukemia (AML), non-Hodgkin's lymphoma (NHL), and chronic lymphocytic leukemia (CLL). Lowsky and colleagues [22] applied TLI/ATG (antithymocyte globulin) conditioning prior to matched sibling donor (MSD) and matched unrelated donor (MUD) HSCT for heavily pretreated adults with AML and mantle cell lymphomas. Thirty-seven initial patients received TLI/ATG, followed by infusion of G-CSF-mobilized PB stem cell grafts. Significant reduction in the incidence and severity of acute GVHD was observed. As in the murine preclinical studies, a profound decrease in the absolute number of conventional $\mathrm{T}$ cells was observed. NKT cells were increased by a factor of 10 among all the $\mathrm{CD} 3^{+} \mathrm{T}$ cells. Antitumor activity was preserved, as evidenced by relapse rate. A recent review of the entire cohort has confirmed this low incidence of GVHD, low mortality, and preserved GVT [23].

\section{ADAPTIVE IMMUNOREGULATORS: Foxp3 ${ }^{+}$NATURAL REGULATORY T CELLS (Treg)}

Evidence exists that significant crosstalk can occur between the innate regulators described earlier and adaptive regulatory $\mathrm{T}$ cells (Treg) during a coordinated immune response, outside of the context of the MHC immune barriers of BMT. Treg are involved both in the pathology of and protection against different immune-mediated diseases. Treg are classified based on their origin (thymically derived versus peripherallyderived), signature transcription factor (Foxp3), phenotypic surface markers (CD45 RA versus RO, HLA-DR), and cytokine profile (TGF- $\beta$ or IL-10) [24]. Treg possessing an $\alpha$-TCR can express the 
coreceptors CD4 or CD8, whereas $\gamma \delta$-TCR-expressing Treg may be double negative. In this section, we concentrate on $\mathrm{CD}^{+}{ }^{+} \mathrm{TCR} \alpha^{+}$Treg that originate naturally in the thymus (nTreg).

Sakaguchi's [25] and Powrie's [26] groups independently described the presence of suppressive $\mathrm{CD} 3{ }^{+} \mathrm{CD} 4{ }^{+} \mathrm{CD} 25^{+} \mathrm{T}$ cells in the thymus in mice and humans, respectively. Papiernik et al. and Romagnani's [27] group demonstrated, using intrathymic labeling, the migration pattern of these cells from thymus to the periphery [28]. Positive selection in the thymus is mediated by MHC Class II-positive thymic cortical epithelial cells (TECs) and requires that Treg have high TCR affinity for MHC-peptide complexes. Contrary to their anergic phenotype in vitro, peripheral Treg proliferate upon receiving cytokine and costimulation-derived signals, such as IL-2 signaling and CD28 costimulation.

Resistance to apoptosis might be conferred by the presence of the surface molecule glucocorticoidinduced TNFR-related protein (GITR). There is great speculation about the mechanisms by which Treg suppress [29-32]. In general, immunosuppression requires TCR-dependent stimulation, cell-to-cell contact (CTLA-4/B7, cytolytic molecules), presence of soluble factors (cytokines, adenosine), and cellular competition with effector T cells for locally available cytokines ( $\gamma$-chain cytokines including IL-2).

Dysregulation of immune responses such as an overexpression of proinflammatory cytokines and reduction of anti-inflammatory cytokines in autoimmunity, and immunosuppression of cytolytic responses in tumors, has significant implications for the application of regulatory $\mathrm{T}$ cells in immunotherapy for malignant and nonmalignant disorders.

\subsection{Murine Regulatory T Cells}

In 2000, Sakaguchi and colleagues demonstrated that murine cells with a regulatory capacity express high and sustained levels of the IL-2 receptor- $\alpha$ chain, CD25. CD ${ }^{+} \mathrm{CD} 4{ }^{+} \mathrm{CD} 25^{+} \mathrm{T}$ cells became the most physiologically relevant Treg population, found to comprise almost $10 \%$ of the total $\mathrm{CD} 3^{+} \mathrm{CD} 4^{+} \mathrm{T}$ cell population in the periphery. The transcription factor Forkhead box P3 (FOXP3) is expressed exclusively in all murine Treg [33-35], making it the best candidate for Treg identification and identifying Treg as a distinct cell lineage. Unfortunately, Foxp3 staining requires fixation and permeabilization of the cells, making them non-viable for further experimentation. Therefore, a significant number of surface markers have been screened in an attempt to identify a unique surface phenotype allowing the isolation of viable Treg. To date, the best surface marker profile for murine Treg with alloregulatory capacity is $\mathrm{CD}^{+}{ }^{+} \mathrm{CD} 4{ }^{+} \mathrm{CD} 25^{+} \mathrm{GITR}^{+}[36,37]$. There is evidence that GITR is overexpressed in tolerant mouse skin grafts when compared to rejected grafts [38]. It is important to emphasize that GITR or other surface markers do not themselves confer regulatory capacity. However, ectopic expression of Foxp3 transforms conventional $\mathrm{T}$ cells into Treg [34]. A well-described murine GFP reporter system developed by the Rudensky lab in which GFP-FoxP3 fusion was inserted at the FoxP3 locus (Foxp3-IRES-GFP knockin) was generated for FACS-based Treg identification and further isolation for ex vivo experimentation [39]. A second knock-in system developed by Flavell's group uses a FoxP3-IRES-mRFP bicistronic system [40]. These systems allowed critical studies that provide essential information about the development and function of Treg.

\subsection{Human Regulatory T Cells}

Human Treg exhibit heterogeneity in their phenotype and function compared to their murine counterparts. In the past decade, human Treg have been classified into more homogenous groups based on their cell-surface markers. Classically, human Treg display the $\mathrm{CD} 3{ }^{+} \mathrm{CD} 4{ }^{+} \mathrm{CD} 25^{\text {bright }} \mathrm{CD} 127^{\mathrm{lo} /-}$ phenotype [41]. The combination of markers typically used to define naïve and memory conventional $\mathrm{T}$ cells serve to further subdivide human Treg $\left(\mathrm{CD} 3^{+} \mathrm{CD} 4{ }^{+} \mathrm{CD} 25^{\text {bright }} \mathrm{CD} 127^{\mathrm{lo} /}-\mathrm{CD} 45 \mathrm{RA}^{+}\right.$and $\mathrm{CD}^{+}{ }^{+} \mathrm{CD} 4{ }^{+} \mathrm{CD} 25^{\text {bright }} \mathrm{CD} 127^{\mathrm{lo} /-} \mathrm{CD} 45 \mathrm{RO}^{+}$, resp.). Miyara et al. and Valmori et al. demonstrated that these subsets differ in their suppressive capacity, with memory Treg being functionally better suppressors and naïve Treg exhibiting weaker suppressive capacity $[42,43]$. Treg with a "naïve" phenotype can 
differentiate to acquire a "memory" phenotype. In adult peripheral blood, the memory Treg are more prevalent than naïve Treg. In contrast, umbilical cord blood-derived Treg predominantly fit the naïve phenotype. Expression of certain costimulatory molecules, such as inducible T-cell costimulator (ICOS), has also shown a high correlation with suppressive activity of human Treg [44].

A major difference between the murine and human Treg is the specificity and stability of Foxp3 [45]. In contrast to the exclusive expression of Foxp3 in murine Treg, human Treg may only transiently express FOXP3. Long-term in vitro studies by Hoffmann et al. [46] showed loss of FOXP3 protein expression during long-term culture and expansion. Suppressive capacity can be also diminished and accompanied by the production of proinflammatory cytokines such as IL-2, IFN- $\gamma$, and IL-17. Besides FOXP3 expression and stability, a second difference is the presence of 4 distinct FOXP3 isoforms at the mRNA level and 3 at the protein level [47]. From the 3 different splice variants at the protein level, the full length (FOXP3FL) and the FOXP3 $\Delta 2$ are most common [48, 49]. Du and colleagues showed that ROR $\alpha$ (a key regulator of IL-17 expression in conjunction with ROR $\gamma \mathrm{t}$ ) suppresses FOXP3 transcription at exon 2 [50]. The mechanisms by which human Treg suppress effector responses appear similar to those described for murine Treg, including cell contact and release of soluble factors such as cytokines and cytolytic molecules [51].

\section{IMMUNOREGULATION BY Treg}

Onizuka et al., investigated the effect of in vivo administration of an anti-CD25 monoclonal antibody on the eradication of different leukemia, myeloma, and sarcoma tumors [52]. Additional studies by Sakaguchi's group confirmed that tumors regress in specific mouse strains as a result of depletion of the CD4 ${ }^{+} \mathrm{CD} 25^{+}$ population [53], suggesting a role for Treg in blocking anti-tumor immunity. Attenuation of the suppressive function of Treg has been linked to a more robust antitumor activity due to enhancement of $\mathrm{T}$ effector function. Blockade of certain Treg-associated proteins, such as IL-2 cytokine and the surface molecule CTLA-4, augments antitumor activity.

Treg are essential for tolerance induction. In 2001, Blazar's group demonstrated that antibodymediated depletion of $\mathrm{CD} 25^{+} \mathrm{T}$ cells abrogated ex vivo induction of tolerance against alloantigens in an allomixed leukocyte reaction (MLR) using C57BL/6 CD4 ${ }^{+}$bulk population or C57BL/6 CD4 ${ }^{+} \mathrm{CD} 25^{-}$ fraction as responder cells and B6.C-H $2^{\mathrm{bm}} 12 / \mathrm{KhEg}\left(\mathrm{C} 56 \mathrm{BL} / 6\right.$ background with MHC-Class II-I ${ }^{\mathrm{A}}$ mutation) splenocytes as allostimulators [54]. Tolerance was dependent on the presence of the $\mathrm{CD} 25^{+}$fraction, because depletion of this population induced hyporesponsiveness to antigen. In vivo, add-back of the $\mathrm{CD} 4{ }^{+} \mathrm{CD} 25^{+}$fraction restored allotolerance in comparison with the addition of $\mathrm{CD} 4{ }^{+} \mathrm{CD} 25^{-}$cells, suggesting a critical role for Treg in regulation of alloresponses. In a series of in vivo experiments using an allogeneic BMT murine model across MHC-Class I and II barriers, Hoffmann and colleagues [55] have shown that Treg of donor origin deliver protection against lethal GVHD induced by donor effector $\mathrm{T}$ cells through IL-10 production (Figure 3). Importantly, GVHD protection does not affect GVT exerted by effector T cells [56]. Subsequent studies by Ermann et al. demonstrated that GVHD prevention in the MHC-mismatched C57BL/6 $\rightarrow$ BALB/c setting is afforded by the CD62L $\mathrm{L}^{+}$(L-selectin chemokine expressing, "naïve") fraction [57]. Additional studies [58] demonstrated that regulatory suppression of GVHD by murine and human Treg preserved thymic and lymphoid architecture of the host and can thereby accelerate post-HSCT T-cell immune reconstitution.

\section{NEW STRATEGIES FOR EX VIVO EXPANSION OF REGULATORY CELLS FOR IMMUNOTHERAPY}

As this review emphasizes, Treg and NKT cells show promise for clinical application in the prevention of GVHD while simultaneously maintaining GVT. Recently, Martelli's [59] group has applied immunotherapy with Treg prior to haploidentical HSCT in patients with hematological malignancies. Following recipient myeloablative conditioning, donor-derived $\mathrm{CD} 25^{+} \mathrm{T}$ cells were infused prior to the infusion of the donor hematopoietic graft. Results were very promising, as only 2 out of 28 patients exhibited GVHD, and patients 

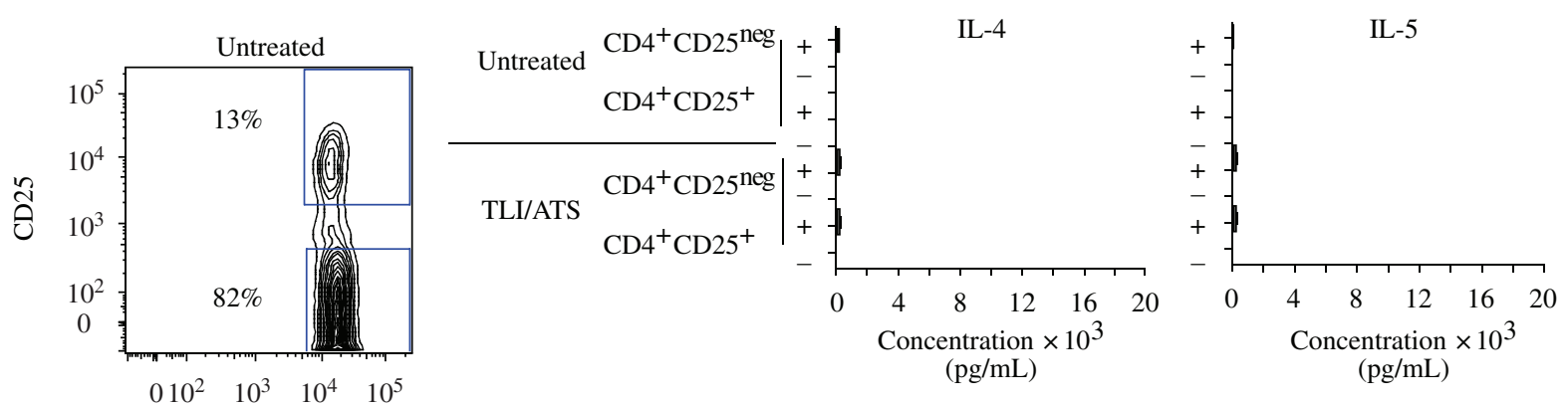

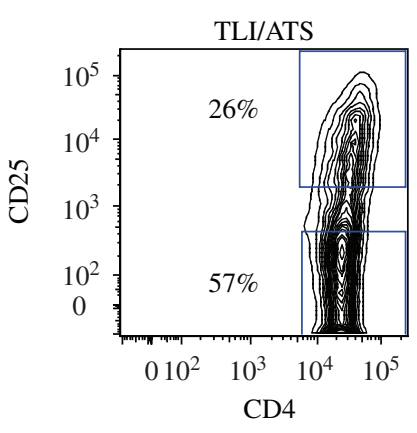

(a)

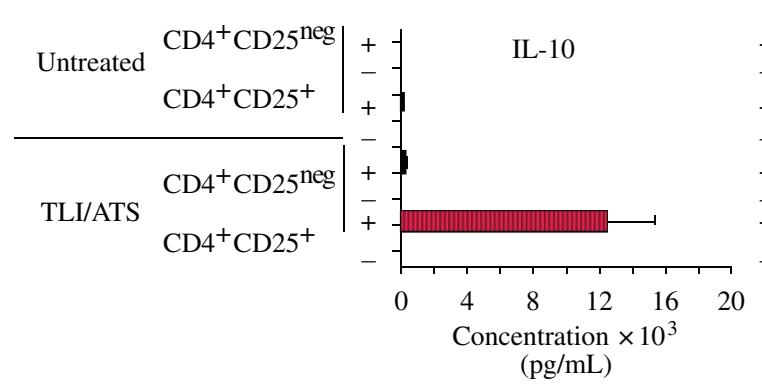

(b)

FIGURE 3: Donor $\mathrm{CD} 4^{+} \mathrm{CD} 25^{+} \mathrm{T}$ cells, which expand in vivo after a nonmyeloablative HSCT conditioning regimen, secrete IL-10 but no IL-4 or IL-5. (a) Representative analysis of in vivo expanded donor $\mathrm{H}-2 \mathrm{~K}^{\mathrm{b}+} \mathrm{CD} 4^{+} \mathrm{CD}_{25}{ }^{+} \mathrm{T}$ cells sorted from recipient mouse spleen at day 6 after allogeneic bone marrow transplantation. (b) Cytokine profile of sorted $\mathrm{CD} 4^{+} \mathrm{CD} 25^{+} \mathrm{T}$ cells. $\mathrm{H}-2 \mathrm{~K}^{\mathrm{b}+} \mathrm{CD} 4^{+} \mathrm{CD} 25^{+}$and $\mathrm{H}$ $2 \mathrm{~K}^{\mathrm{b}+\mathrm{CD}} 4^{+} \mathrm{CD} 25^{-}$splenocytes were sorted from spleens of wild-type C57BL/6 mice (untreated, UNT) or from wild-type BALB/c hosts conditioned with TLI/ATS, transplanted with bone marrow and spleen cells from a wild-type C57BL/ 6 donor, and harvested on day 6 after transplant. A total of $4 \times 10^{4}$ cells/well were incubated in triplicate wells for $72 \mathrm{hrs}$ with or without $10 \mathrm{ng} / \mathrm{mL}$ myristate acetate (PMA) $+2 \mu \mathrm{M}$ ionomycin. Supernatants were analyzed by 22-plex Milliplex Map mouse cytokine/chemokine kit (Millipore, Mass, USA). Data represent means \pm SEM of triplicate wells in 3 experiments, $n=4-6$ mice per experiment (TLI/ATS group) and $n=5-7$ mice per experiment (Untreated group). TLI/ATS: total lymphoid irradiation/antithymocyte setum.

overall had early immune T-cell reconstitution. Follow-up of relapse rate in these patients is needed to confirm whether Treg infusion alters long-term GVT in the haplo-HSCT setting.

We are optimizing a protocol for iNKT expansion from different cellular therapy sources including peripheral blood-derived mononuclear cells (Luszczek, Morales-Tirado, and Pillai, unpublished) using antiCD3. The goal of iNKT expansion is to apply them to suppress GVHD while simultaneously maintaining GVT in HSCT, as well as to augment immunotherapy of tumors in the non-HSCT setting.

Suppression of immune responses by Treg makes them an attractive candidate for immunotherapy [60]. However, the relative scarcity of this population the known expression of growth inhibitory genes such as members at the SOCS family and PD-1 molecule, imposes limitations on their ex vivo expansion. Breaking cell cycle arrest is critical to allow expansion; approaches including coculture with immunomodulatory APCs have been examined to optimize Treg activation and expansion in vitro. To date, these dominantly include TCR-triggering/costimulation ("Signals 1 and 2"), cytokine/cytokine receptor modulation ("Signal 3"), and immunosuppressive and environmental compounds which achieve Signals 1-3. Signal 1 through the TCR and Signal 2 through costimulatory molecules (CD28) activate downstream signaling pathways that ultimately lead to the activation of the transcription factors NFAT and NF $\kappa$, breaking the constitutively nonproliferative state of resting Treg. Both in mice and humans, IL- 2 and TGF- $\beta$ 


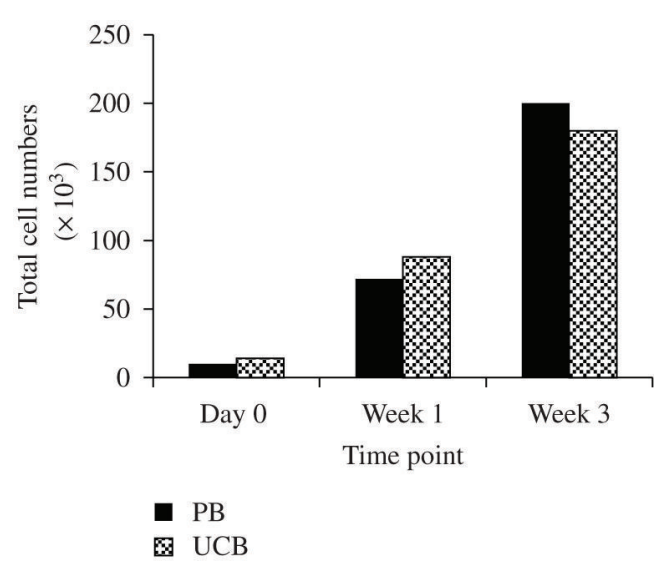

(a)

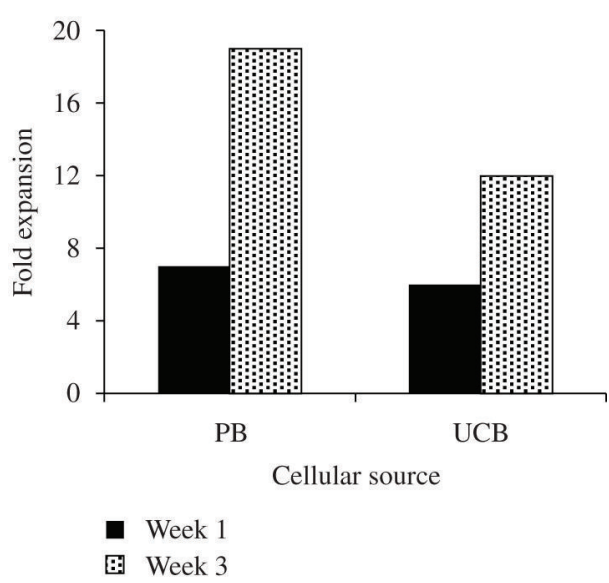

(b)

FIGURE 4: Ex vivo expansion of $\mathrm{CD} 3^{+} \mathrm{CD} 4^{+} \mathrm{CD} 25^{+} \mathrm{CD} 127^{\mathrm{lo}} \mathrm{nTreg}$ from adult peripheral blood (PB) and umbilical cord blood (UCB)-derived mononuclear cells. (a) Total cell numbers of cultured nTreg. FACSsorted $\mathrm{CD} 3^{+} \mathrm{CD} 4^{+} \mathrm{CD} 25^{+} \mathrm{T}$ cells were cultured with Rapamycin and rhIL-2 for 21 days. (b) Fold expansion (from baseline absolute number at start of expansion) of ex vivo expanded nTreg from PB and UCB.

are the two main cytokines used to augment Signal 3, prevent apoptosis, and possibly to sustain of FOXP3 expression. Rapamycin, a small molecule inhibitor of the mTOR-AKT pathway, promotes growth and selective expansion of both human and murine $\mathrm{CD} 3{ }^{+} \mathrm{CD} 4^{+} \mathrm{CD} 25^{+} \mathrm{FOXP} 3{ }^{+}$Treg [61-63]. Environmental compounds such as $1 \alpha, 25$-dihydroxy vitamin D (vitamin D3) have been shown in murine studies to augment expansion of antigen-specific Treg in vivo and polyclonal Treg in vitro. A recent study of vitamin D3 in human Treg has further demonstrated modulation of FOXP3 and increase in Treg suppressive function [64].

Current expansion protocols use high doses of recombinant human IL-2 ( $\geq 100 \mathrm{U} / \mathrm{mL}$ rhIL-2) that may require continuous supply of the cytokine after infusion. We have found that, when coupled with appropriate APC stimuli, low concentrations of rhIL-2 in combination with rapamycin can still achieve significant growth and expansion of Treg from relevant human cellular therapy sources, as shown in Figure 4 (Morales-Tirado and Pillai, unpublished).

In addition to expansion of Treg, significant efforts have been targeted to the induction of Treg (iTr) from conventional $\left(\mathrm{CD} 4{ }^{+} \mathrm{CD} 25^{\text {neg }}\right.$ Foxp $\left.3^{\text {neg }}\right) \mathrm{T}$ cells. These populations differ from Treg in their modes of induction, cytokine profile, and mechanisms of suppressor activity. Reviews on these populations can be found elsewhere [65-67]. Despite encouraging data with cellular expansions, there remains significant debate regarding stability of their suppressor phenotype (i.e., avoidance of reversion into an effector T-cell population with proinflammatory rather than regulatory properties).

Although advances in chemotherapy and ancillary care have rendered pediatric leukemias largely curable by chemotherapy alone, there remain many challenges in pediatric oncology which are amenable to cellular immunotherapy. These include postchemotherapy consolidative immunotherapy for leukemias and high-risk solid tumors such as advanced-stage or unfavorably located sarcomas, non-radio-responsive central nervous system tumors, consolidative therapy after-transplant, and regulation of adverse immune complications such as GVHD or delayed immune reconstitution after transplant.

Pretransplant conditioning regimens that enrich endogenously for regulatory cell populations hold similar promise as methods of immunotherapy. Our group recently has performed a retrospective review in a small cohort of pediatric patients treated for severe aplastic anemia (SAA) [68]. Although in few patients, the data suggested comparable results between MSD and MUD HSCT using TLI/ATG in combination with cyclophosphamide (CTX) conditioning. Future studies including a larger cohort of pediatric patients in clinical trial to investigate TLI/ATG with CTX conditioning versus standard therapy are necessary to study 
mechanisms of induction tolerance. The outcomes of these studies will give us information applicable for SAA and other diseases that are otherwise curable by application of HSCT.

Rapid and profound progress has been made in the past fifty years in the clinical field of hematopoietic cell transplantation. However, fine-tuning disease treatment, minimizing toxicity of the therapy, GVHD prevention, stabilizing engraftment, and maintaining remission from malignant disease by sustained GVT and tumor eradication remain the major challenges. Crosstalk and immunoregulation by NKT and Treg, as discussed here, have clinical potential to separate GVHD and GVT after allotransplantation and deserve focused translational study with varied conditioning regimens and in specific donor-recipient contexts.

\section{ACKNOWLEDGMENTS}

The authors would like to thank Taren Ong for technical assistance, Dr. Richard Ashmun and the St. Jude Children's Research Hospital (SJCRH) Flow Cytometry and Cell Sorting Share Resource for assistance with flow cytometry, and Dr. Terrence Geiger (SJCRH Blood Donor Center) and Dr. Paul Eldridge (SJCRH Human Applications Laboratory) for cellular products. This work was supported in part by the American Lebanese and Syrian Associated Charities (ALSAC), the Sumara Endowed Fellowship in Cellular and Gene Therapy (MVDM), NHLBI \#5K08HL088260 (AP), NCI/St. Jude Cancer Center Support Grant (AP), and Hyundai Foundation (AP).

\section{REFERENCES}

[1] D. W. Barnes, M. J. Corp, J. F. Loutit, and F. E. Neal, "Treatment of murine leukaemia with X rays and homologous bone marrow; preliminary communication," The British Medical Journal, vol. 2, pp. 626-627, 1956.

[2] D. W. Barnes and J. F. Loutit, "Treatment of murine leukaemia with x-rays and homologous bone marrow. II," The British Journal of Haematology, vol. 3, pp. 241-252, 1957.

[3] D. W. Barnes and J. F. Loutit, "'Secondary disease" of radiation chimeras: a syndrome due to lymphoid aplasia," Annals of the New York Academy of Sciences, vol. 99, pp. 374-385, 1962.

[4] E. D. Thomas, H. L. Lochte Jr., J. H. Cannon, O. D. Sahler, and J. W. Ferrebee, "Supralethal whole body irradiation and isologous marrow transplantation in man," The Journal of Clinical Investigation, vol. 38, pp. 1709-1716, 1959.

[5] G. Mathe, J. L. Amiel, L. Schwarzenberg, A. Cattan, and M. Schneider, "Adoptive immunotherapy of acute leukemia: experimental and clinical results," Cancer Research, vol. 25, no. 9, pp. 1525-1531, 1965.

[6] H. E. Kohrt, A. B. Pillai, R. Lowsky, and S. Strober, "NKT cells, Treg, and their interactions in bone marrow transplantation," European Journal of Immunology, vol. 40, no. 7, pp. 1862-1869, 2010.

[7] C. A. Wysocki, A. Panoskaltsis-Mortari, B. R. Blazar, and J. S. Serody, "Leukocyte migration and graft-versushost disease," Blood, vol. 105, no. 11, pp. 4191-4199, 2005.

[8] R. E. Billingham, “The biology of graft-versus-host reactions," Harvey Lectures, vol. 62, pp. 21-78, 1966.

[9] A. Bendelac, P. B. Savage, and L. Teyton, "The biology of NKT cells," Annual Review of Immunology, vol. 25, pp. 297-336, 2007.

[10] L. Wu and L. Van Kaer, "Natural killer T cells in health and disease," Frontiers in Bioscience, vol. 3, pp. 236-251, 2011.

[11] T. Kawano, J. Cui, Y. Koezuka et al., "CD1d-restricted and TCR-mediated activation of V $(\alpha) 14$ NKT cells by glycosylceramides," Science, vol. 278, no. 5343, pp. 1626-1629, 1997.

[12] D. Zeng, D. Lewis, S. Dejbakhsh-Jones et al., "Bone marrow NK1.1(-) and NK1.1(+) T cells reciprocally regulate acute graft versus host disease," Journal of Experimental Medicine, vol. 189, no. 7, pp. 1073-1081, 1999.

[13] O. Lantz and A. Bendelac, "An invariant $\mathrm{T}$ cell receptor $\alpha$ chain is used by a unique subset of major histocompatibility complex class I-specific CD4+ and CD4-8- T cells in mice and humans," Journal of Experimental Medicine, vol. 180, no. 3, pp. 1097-1106, 1994.

[14] M. Exley, J. Garcia, S. P. Balk, and S. Porcelli, "Requirements for CD1d recognition by human invariant V $\alpha 24+$ CD4- CD8- T cells," Journal of Experimental Medicine, vol. 186, no. 1, pp. 109-120, 1997. 
[15] M. A. Exley, R. Hou, A. Shaulov et al., "Selective activation, expansion, and monitoring of human iNKT cells with a monoclonal antibody specific for the TCR $\alpha$-chain CDR3 loop," European Journal of Immunology, vol. 38, no. 6, pp. 1756-1766, 2008.

[16] M. A. Exley, S. P. Balk, and S. B. Wilson, "Isolation and functional use of human NK T cells," Current Protocols in Immunology, chapter 14, unit 14.11, 2003.

[17] F. Lan, D. Zeng, M. Higuchi, J. P. Higgins, and S. Strober, "Host conditioning with total lymphoid irradiation and antithymocyte globulin prevents graft-versus-host disease: the role of CD1-reactive natural killer T cells," Biology of Blood and Marrow Transplantation, vol. 9, no. 6, pp. 355-363, 2003.

[18] D. Hashimoto, S. Asakura, S. Miyake et al., "Stimulation of host NKT cells by synthetic glycolipid regulates acute graft-versus-host disease by inducing Th2 polarization of donor T cells," Journal of Immunology, vol. 174, no. 1, pp. 551-556, 2005.

[19] A. B. Pillai, T. I. George, S. Dutt, P. Teo, and S. Strober, "Host NKT cells can prevent graft-versus-host disease and permit graft antitumor activity after bone marrow transplantation," Journal of Immunology, vol. 178, no. 10, pp. 6242-6251, 2007.

[20] D. B. Leveson-Gower, J. A. Olson, E. I. Sega et al., "Low doses of natural killer T cells provide protection from acute graft-versus-host disease via an IL-4-dependent mechanism," Blood, vol. 117, no. 11, pp. 3220-3229, 2011.

[21] A. B. Pillai, T. I. George, S. Dutt, and S. Strober, "Host natural killer T cells induce an interleukin-4-dependent expansion of donor CD4+CD25+Foxp3+ T regulatory cells that protects against graft-versus-host disease," Blood, vol. 113, no. 18, pp. 4458-4467, 2009.

[22] R. Lowsky, T. Takahashi, P. L. Yin et al., "Protective conditioning for acute graft-versus-host disease," The New England Journal of Medicine, vol. 353, no. 13, pp. 1321-1331, 2005.

[23] H. E. Kohrt, B. B. Turnbull, K. Heydari et al., "TLI and ATG conditioning with low risk of graft-versus-host disease retains antitumor reactions after allogeneic hematopoietic cell transplantation from related and unrelated donors," Blood, vol. 114, no. 5, pp. 1099-1109, 2009.

[24] G. L. Cvetanovich and D. A. Hafler, "Human regulatory T cells in autoimmune diseases," Current Opinion in Immunology, vol. 22, no. 6, pp. 753-760, 2010.

[25] S. Sakaguchi, N. Sakaguchi, M. Asano, M. Itoh, and M. Toda, "Immunologic self-tolerance maintained by activated T cells expressing IL- 2 receptor $\alpha$-chains (CD25): breakdown of a single mechanism of self-tolerance causes various autoimmune diseases," Journal of Immunology, vol. 155, no. 3, pp. 1151-1164, 1995.

[26] F. Powrie and D. Mason, "OX-22(high) CD4+ T cells induce wasting disease with multiple organ pathology: prevention by the OX-22(low) subset," Journal of Experimental Medicine, vol. 172, no. 6, pp. 1701-1708, 1990.

[27] F. Annunziato, P. Romagnani, L. Cosmi, E. Lazzeri, and S. Romagnani, "Chemokines and lymphopoiesis in human thymus," Trends in Immunology, vol. 22, no. 5, pp. 277-281, 2001.

[28] M. Papiernik, M. L. De Moraes, C. Pontoux, F. Vasseur, and C. Pénit, "Regulatory CD4 T cells: expression of IL-2R $\alpha$ chain, resistance to clonal deletion and IL-2 dependency," International Immunology, vol. 10, no. 4, pp. 371-378, 1998.

[29] D. K. Sojka, Y. H. Huang, and D. J. Fowell, "Mechanisms of regulatory T-cell suppression—a diverse arsenal for a moving target," Immunology, vol. 124, no. 1, pp. 13-22, 2008.

[30] S. Sakaguchi, "Naturally arising Foxp3-expressing CD25+ CD4+ regulatory T cells in immunological tolerance to self and non-self," Nature Immunology, vol. 6, no. 4, pp. 345-352, 2005.

[31] E. M. Shevach, "Special regulatory T cell review: how I became a T suppressor/regulatory cell maven," Immunology, vol. 123, no. 1, pp. 3-5, 2008.

[32] D. A. Vignali, L. W. Collison, and C. J. Workman, "How regulatory T cells work," Nature Reviews Immunology, vol. 8, no. 7, pp. 523-532, 2008.

[33] J. D. Fontenot, M. A. Gavin, and A. Y. Rudensky, "Foxp3 programs the development and function of CD4+CD25+ regulatory T cells," Nature Immunology, vol. 4, no. 4, pp. 330-336, 2003.

[34] S. Hori, T. Nomura, and S. Sakaguchi, "Control of regulatory T cell development by the transcription factor Foxp3," Science, vol. 299, no. 5609, pp. 1057-1061, 2003.

[35] R. Khattri, T. Cox, S. A. Yasayko, and F. Ramsdell, "An essential role for Scurfin in CD4+CD25+ T regulatory cells," Nature Immunology, vol. 4, no. 4, pp. 337-342, 2003.

[36] J. Shimizu, S. Yamazaki, T. Takahashi, Y. Ishida, and S. Sakaguchi, "Stimulation of CD25+CD4+ regulatory T cells through GITR breaks immunological self-tolerance,” Nature Immunology, vol. 3, no. 2, pp. 135-142, 2002. 
[37] R. S. McHugh, M. J. Whitters, C. A. Piccirillo et al., "CD4+CD25+ Immunoregulatory T Cells: gene expression analysis reveals a functional role for the glucocorticoid-induced TNF receptor," Immunity, vol. 16, no. 2, pp. 311-323, 2002.

[38] D. Zelenika, E. Adams, S. Humm et al., "Regulatory T cells overexpress a subset of Th2 gene transcripts," Journal of Immunology, vol. 168, no. 3, pp. 1069-1079, 2002.

[39] J. D. Fontenot, J. P. Rasmussen, L. M. Williams, J. L. Dooley, A. G. Farr, and A. Y. Rudensky, "Regulatory T cell lineage specification by the forkhead transcription factor Foxp3," Immunity, vol. 22, no. 3, pp. 329-341, 2005.

[40] Y. Y. Wan and R. A. Flavell, "Identifying Foxp3-expressing suppressor T cells with a bicistronic reporter," Proceedings of the National Academy of Sciences of the United States of America, vol. 102, no. 14, pp. 51265131, 2005.

[41] W. Liu, A. L. Putnam, Z. Xu-yu et al., "CD127 expression inversely correlates with FoxP3 and suppressive function of human CD4+ T reg cells," Journal of Experimental Medicine, vol. 203, no. 7, pp. 1701-1711, 2006.

[42] M. Miyara, Y. Yoshioka, A. Kitoh et al., "Functional delineation and differentiation dynamics of human CD4+ T cells expressing the FoxP3 transcription factor," Immunity, vol. 30, no. 6, pp. 899-911, 2009.

[43] D. Valmori, A. Merlo, N. E. Souleimanian, C. S. Hesdorffer, and M. Ayyoub, "A peripheral circulating compartment of natural naive CD4+ Tregs," Journal of Clinical Investigation, vol. 115, no. 7, pp. 1953-1962, 2005.

[44] M. Vocanson, A. Rozieres, A. Hennino et al., "Inducible costimulator (ICOS) is a marker for highly suppressive antigen-specific T cells sharing features of TH17/TH1 and regulatory T cells," Journal of Allergy and Clinical Immunology, vol. 126, no. 2, pp. 280-289, 2010.

[45] S. F. Ziegler, "FOXP3: of mice and men," Annual Review of Immunology, vol. 24, pp. 209-226, 2006.

[46] P. Hoffmann, T. J. Boeld, R. Eder et al., "Loss of FOXP3 expression in natural human CD4+ CD25+ regulatory T cells upon repetitive in vitro stimulation," European Journal of Immunology, vol. 39, no. 4, pp. 1088-1097, 2009.

[47] L. M. Ebert, S. T. Bee, J. Browning et al., "The regulatory T cell-associated transcription factor FoxP3 is expressed by tumor cells," Cancer Research, vol. 68, no. 8, pp. 3001-3009, 2008.

[48] T. Aarts-Riemens, M. E. Emmelot, L. F. Verdonck, and T. Mutis, "Forced overexpression of either of the two common human Foxp3 isoforms can iduce regulatory T cells from CD4+CD25- cells," European Journal of Immunology, vol. 38, no. 5, pp. 1381-1390, 2008.

[49] S. E. Allan, L. Passarini, R. Bacchetta et al., "The role of 2 FOXP3 isoforms in the generation of human CD4+ Tregs," Journal of Clinical Investigation, vol. 115, no. 11, pp. 3276-3284, 2005.

[50] J. Du, C. Huang, B. Zhou, and S. F. Ziegler, "Isoform-specific inhibition of ROR $\alpha$-mediated transcriptional activation by human FOXP3," Journal of Immunology, vol. 180, no. 7, pp. 4785-4792, 2008.

[51] C. W. Ashley and C. Baecher-Allan, "Cutting edge: responder T cells regulate human DR+ effector regulatory T cell activity via Granzyme B,” Journal of Immunology, vol. 183, no. 8, pp. 4843-4847, 2009.

[52] S. Onizuka, I. Tawara, J. Shimizu, S. Sakaguchi, T. Fujita, and E. Nakayama, "Tumor rejection by in vivo administration of anti-CD25 (interleukin-2 receptor $\alpha$ ) monoclonal antibody," Cancer Research, vol. 59, no. 13, pp. 3128-3133, 1999.

[53] J. Shimizu, S. Yamazaki, and S. Sakaguchi, "Induction of tumor immunity by removing CD25+CD4+ T cells: a common basis between tumor immunity and autoimmunity," Journal of Immunology, vol. 163, no. 10, pp. 5211-5218, 1999.

[54] P. A. Taylor, R. J. Noelle, and B. R. Blazar, "CD4+CD25+ immune regulatory cells are required for induction of tolerance to alloantigen via costimulatory blockade," Journal of Experimental Medicine, vol. 193, no. 11, pp. 1311-1317, 2001.

[55] P. Hoffmann, J. Ermann, M. Edinger, C. Garrison Fathman, and S. Strober, "Donor-type CD4+CD25+ regulatory T cells suppress lethal acute graft-versus-host disease after allogeneic bone marrow transplantation," Journal of Experimental Medicine, vol. 196, no. 3, pp. 389-399, 2002.

[56] M. Edinger, P. Hoffmann, J. Ermann et al., "CD4+CD25+ regulatory T cells preserve graft-versus-tumor activity while inhibiting graft-versus-host disease after bone marrow transplantation," Nature Medicine, vol. 9, no. 9, pp. 1144-1150, 2003.

[57] J. Ermann, P. Hoffmann, M. Edinger et al., "Only the CD62L+ subpopulation of CD4+CD25+ regulatory T cells protects from lethal acute GVHD,” Blood, vol. 105, no. 5, pp. 2220-2226, 2005. 
[58] V. H. Nguyen, R. Zeiser, D. L. DaSilva et al., "In vivo dynamics of regulatory T-cell trafficking and survival predict effective strategies to control graft-versus-host disease following allogeneic transplantation," Blood, vol. 109, no. 6, pp. 2649-2656, 2007.

[59] M. Di Ianni, F. Falzetti, A. Carotti et al., "Tregs prevent GVHD and promote immune reconstitution in HLAhaploidentical transplantation," Blood, vol. 117, no. 14, pp. 3921-3928, 2011.

[60] J. L. Riley, C. H. June, and B. R. Blazar, "Human T regulatory cell therapy: take a billion or so and call me in the morning," Immunity, vol. 30, no. 5, pp. 656-665, 2009.

[61] M. Battaglia, A. Stabilini, B. Migliavacca, J. Horejs-Hoeck, T. Kaupper, and M. G. Roncarolo, "Rapamycin promotes expansion of functional CD4+CD25 +FOXP3+ regulatory T cells of both healthy subjects and type 1 diabetic patients," Journal of Immunology, vol. 177, no. 12, pp. 8338-8347, 2006.

[62] M. Battaglia, A. Stabilini, and M. G. Roncarolo, "Rapamycin selectively expands CD4+CD25+FoxP3 + regulatory T cells," Blood, vol. 105, no. 12, pp. 4743-4748, 2005.

[63] L. Passerini, S. E. Allan, M. Battaglia et al., "STAT5-signaling cytokines regulate the expression of FOXP3 in CD4+CD25+ regulatory T cells and CD4+ CD25- effector T cells," International Immunology, vol. 20, no. 3, pp. 421-431, 2008.

[64] V. Morales-Tirado, D. G. Wichlan, T. E. Leimig, S. E. Street, K. A. Kasow, and J. M. Riberdy, "1alpha,25dihydroxyvitamin D3 (vitamin D3) catalyzes suppressive activity on human natural regulatory T cells, uniquely modulates cell cycle progression, and augments FOXP3," Clinical Immunology, vol. 138, pp. 212-221, 2011.

[65] S. E. Allan, R. Broady, S. Gregori et al., "CD4+ T-regulatory cells: toward therapy for human diseases," Immunological Reviews, vol. 223, no. 1, pp. 391-421, 2008.

[66] M. K. Levings and M. G. Roncarolo, "Phenotypic and functional differences between human CD4 +CD25+ and type 1 regulatory T cells," Current Topics in Microbiology and Immunology, vol. 293, pp. 303-326, 2005.

[67] M. G. Roncarlo and S. Gregori, "Is FOXP3 a bona fide marker for human regulatory T cells?" European Journal of Immunology, vol. 38, no. 4, pp. 925-927, 2008.

[68] A. Pillai, C. Hartford, C. Wang et al., "Favorable preliminary results using TLI/ATG-based immunomodulatory conditioning for matched unrelated donor allogeneic hematopoietic stem cell transplantation in pediatric severe aplastic anemia," Pediatric Transplantation, vol. 15, no. 6, pp. 628-634, 2011.

\section{This article should be cited as follows:}

Vanessa Morales-Tirado, Wioleta Luszczek, Marié van der Merwe, and Asha Pillai, "Regulatory Immunotherapy in Bone Marrow Transplantation," TheScientificWorldJOURNAL, vol. 11, pp. 2620-2634, 2011. 


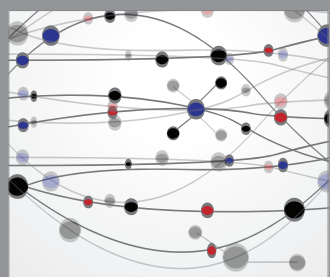

The Scientific World Journal
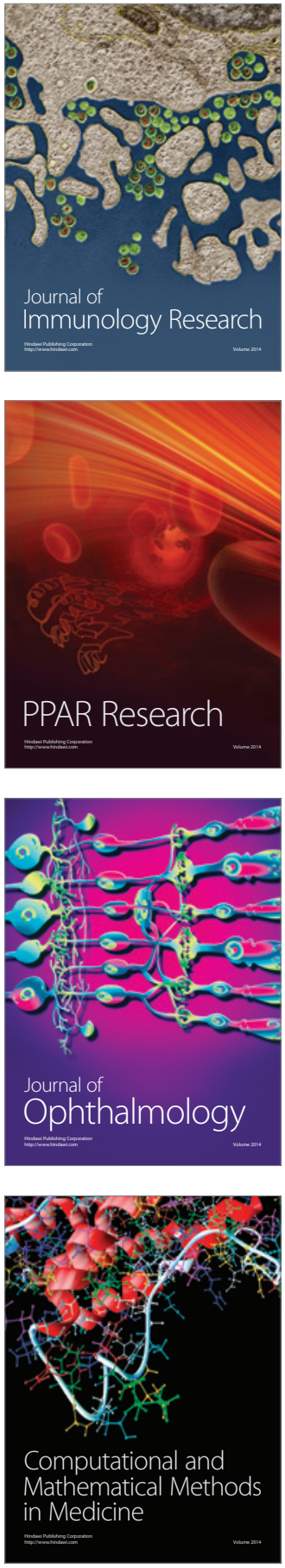

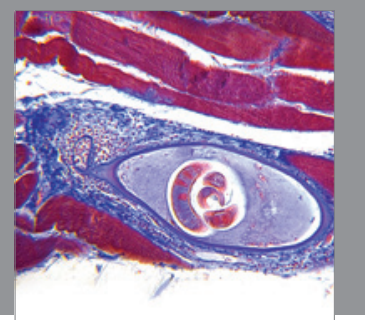

Gastroenterology

Research and Practice
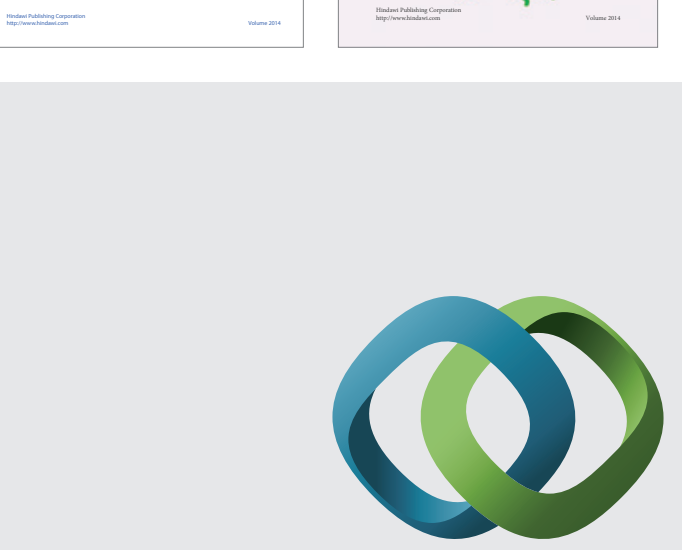

\section{Hindawi}

Submit your manuscripts at

http://www.hindawi.com
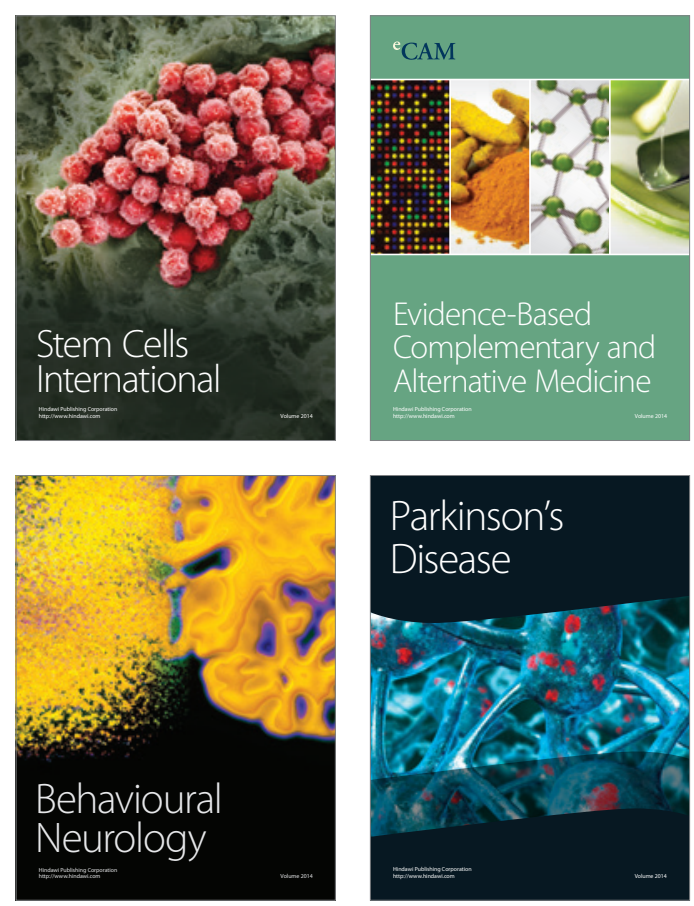

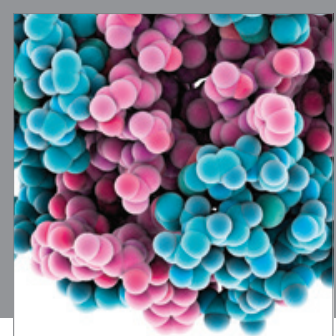

Journal of
Diabetes Research

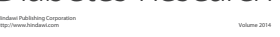

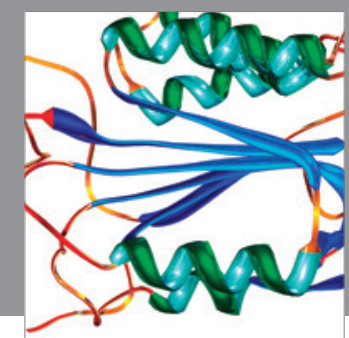

Disease Markers
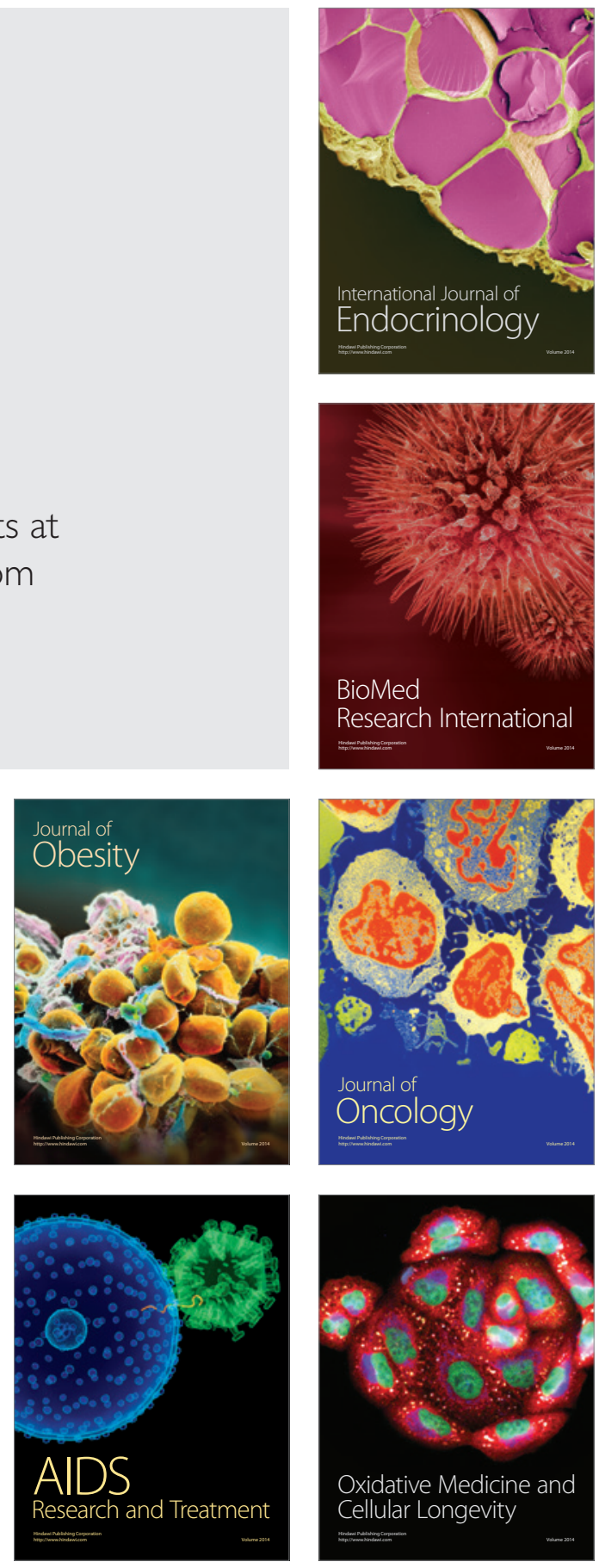